\title{
ASPEK IBADAH, LATIHAN SPRITUAL DAN AJARAN MORAL (Studi Pemikiran Harun Nasution tentang Pokok-Pokok Ajaran Islam)
}

\author{
Khoiruman* \\ E-mail: guschoioke@gmail.com
}

Abstrak

Penelitian ini berawal dari kebanyakan umat Islam yang belum mampu memahami dan mengamalkan pokok ajaran Agama Islam, yaitu akidah, akhlak, dan syariah secara integral. Tujuan tulisan ini adalah memahami pemikiran dari Harun Nasution tentang bagaimana seorang Muslim harus memahami pokok-pokok ajaran Islam secara terintegrasi antara akidah, akhlak dan syariah. Pendekatan dari pengkajian ini adalah pendekatan doktriner Filosofis, penelitian Eksploratif Deskriptif dengan menggunakan pendekatan kesejarahan, metode Komparasi (perbandingan) dan pendekatan Aliran. Hasil dari tulisan ini menjelaskan bahwa menurut Harun Nasution Idealnya pokok-pokok ajaran Islam (Akidah, Syari'ah, dan Akhlaq) itu harus dipahami dan dilaksanakan secara integral untuk menuju kepada kesempurnaan manusia (insan kamil), karena pada hakekatnya manusia itu harus senantiasa meningkatkan hubungan baiknya dengan Allah, manusia dan alam semesta.

Kata Kunci : Ibadat, Spritual, Moral

\section{Pendahuluan}

Kehadiran Agama Islam yang dibawa Nabi Muhammad Saw. Diyakini dapat menjamin terwujudnya kehidupan manusia yang sejahtera lahir dan batin. Hal ini disebabkan Agama Islam adalah agama yang Universal yang berisi petunjuk hidup manusia yang tidak akan pernah usang ajaran-ajarannya, karena senantiasa sesuai dengan kondisi ruang dan waktu.

Sebagai penyempurna dari agama agama samawi, maka Islam mempunyai pokok-pokok ajaran yang lengkap yang dapat mencukupi kebutuhan eksistensi manusia dalam rangka menjalankan tugas sebagai kholifah dan hamba Allah dimuka bumi ini. Pokok-pokok ajaran itu adalah Akidah, Syari'ah, dan Akhlaq, rincian tersebut dipahami dari percakapan Nabi dengan malaikat jibril tentang makna Iman, Islam dan Ihsan. Artinya siapa saja yang mampu mengaktualisasikan pokokpokok ajaran islam itu secara integral dipastikan orang tersebut akan mendapatkan kebahagiaan di dunia dan akhirat.

Meskipun demikian, dalam Realitasnya tidak semua orang mampu memahami pokok-pokok Islam secara integral. Ada sebagian orang yang dalam hidupnya lebih menonjolkan akidahnya, 
tapi mengenyampingkan aspek syari'ah dan Akhlaknya, maka yang terjadi adalah banyak orang yang percaya terhadap Tuhan, tapi dia tidak mau sholat, dan suka menyakiti hati sesama manusia. Disisi lain banyak orang yang dalam beragama mengedepankan syari'ah tapi mengesampingkan aspek akidah dan akhlak, maka orang tersebut dalam kehidupan beragamanya bisa jadi rajin sholat tapi masih rajin korupsi, dan suka mendzolimi sesamanya. Ada juga tipe orang yang lebih mengedepankan aspek akhlaknya, tapi tidak menghiraukan aspek akidah dan syariatnya, maka akibatnya dia akan menjadi orang tidak ikhlas dalam setiap perbuatannya. Orang ini senantiasa cari muka, dan berbuat sesuai dengan kepentingan keduniaan saja.

Dari realitas tersebut maka perlu ada pendekatan - pendekatan pengakajian tentang pokok-pokok ajaran Islam yang mampu menjelaskan keterkaitan pokok-pokok ajaran tersebut dalam rangka untuk diaktualisasikan dalam kehidupan sehari-hari. Maka tulisan ini akan mencoba mencari pendekatan yang terbaik dalam memahami pokok-pokok ajaran Islam secara integral yang pada akhirnya bisa diejawentahkan dalam kehidupan seharihari.

\section{A. Biografi Singkat Harun Nasution}

Prof. Dr. Harun Nasution (lahir di Pematangsiantar, Sumatra Utara, 23 September 1919 - wafat di Jakarta tanggal 18 September 1998) adalah seorang akademisi, intelektual, pemikir, filsuf dan tokoh muslim Indonesia. Pernah menjabat sebagai rektor IAIN Syarif Hidayatullah. ${ }^{1}$

Harun Nasution bersekolah di HIS (Hollandsche Indlansche School) dan lulus pada tahun 1934. Pada tahun 1937, lulus dari Moderne Islamietische Kweekschool. Ia melanjutkan pendidikan di Ahliyah Universitas Al-Azhar pada tahun 1940. Dan pada tahun 1952, meraih gelar sarjana muda di American University of Cairo.

Harun Nasution menjadi pegawai Deplu Brussels dan Kairo pada tahun 1953-1960. Dia meraih gelar doktor di Universitas McGill di Kanada pada tahun 1968. Selanjutnya, pada 1969 menjadi rektor di IAIN Syarif Hidayatullah dan Universitas Negeri Jakarta. Pada tahun 1973, menjabat sebagai rektor IAIN Syarif Hidayatullah. Harun Nasution wafat pada tanggal 18 September 1998 di Jakarta.

Disamping sebagai seorang pengajar, Harun Nasution juga dikenal sebagai penulis.

Beberapa buku yang pernah ditulis oleh Harun Nasution antara lain :

- Akal dan Wahyu dalam Islam (1981)

- Filsafat Agama (1973) 
- Islam Rasional (1995)

- Sejarah Pemikiran dan Gerakan

- Islam ditinjau dari berbagai aspeknya

- Teologi islam²

\section{B. Metedologi Pengkajian}

Perdebatan tentang perlunya perangkat analisis dan metodologis dalam studi Islam (Dirasah Islamiyah) merupakan agenda yang tidak pernah berhenti diperbincangkan oleh kalangan akademis dan intelektual di Indonesia. Gagasan untuk mengkaji Islam dari berbagai interdisipliner merupakan kebutuhan atas usaha bagaimana Islam menjawab berbagai tantangan sosial kemasyarakatan. Islam sebagai agama yang relevan dalam situasi dan kondisi apa pun (al-Islam Shalih likulli zaman wa makan) mendapat tantangan, terutama bagi penganutnya, untuk memberi interpretasi atas ajaran-ajaran Islam yang ada. Sudah diyakini bahwa wahyu Islam telah berhenti, sementara itu, problematika sosial umat manusia senantiasa berkembang dan kompleks. Oleh karena itu, tidak bisa tidak penganut agama Islam harus mampu memberikan respons dengan memberikan elaborasi, tentunya interpretasi di dalamnya, atas ajaran Islam dari sumbernya, al-Qur'an-alHadits.

Jika sesorang melihat Islam hanya dari satu sudut pandang saja, dia hanya melihat satu dimensi dari sebuah kristal yang berisi banyak. Jika seseorang melihat suatu persoalan dengan benar, dia akan menyadari bahwa hanya dengan memiliki pengetahuan umum tentang Islam, tidaklah cukup. Al- Qur'an sendiri merupakan contoh ajaran ajaran yang berdimensi banyak. Sepanjang sejarah, ilmu pengetahuan telah ditarik dari alQur'an. ${ }^{3}$

Para ahli sudah banyak memberikan macam- macam pendekatan dalam memahami Islam, Harun Nasution sebagaimana dikutip Abudin Nata menjelaskan bahwa dalam penelitian Hukum Islam bisa menggunakan penelitian eksploratif dan deskriptif dengan menggunakan pendekatan kesejarahan. Interpretasi yang dilakukan atas data-data historis tersebut selalu dikaitkan dengan konteks sejarahnya. ${ }^{4}$ Disisi lain Ali Syari'ati misalnya memberi tawaran dalam memahami Islam dengan metode Komperasi (perbandingan) dan pendekatan Aliran. Menurutnya, dengan pendekatan perbandingan (komparasi) dapat diketahui kelebihan dan kekurangan yang terdapat diantara berbagai yang 
dibandingkan itu, contoh salah satu cara mengenal Allah adalah dengan membandingkan-Nya dengan sesembahan agama-agama lain. Cara memahami al-Qur'an dengan membandingkannya dengan kitab-kitab samawi lainnya. Namun sebagaimana diketahui bahwa secara akademis suatu perbandingan memerlukan persyaratan tertentu. Perbandingan menghendaki objektivitas, tidak ada pemihakan, tidak ada prakonsepsi, dan semacamnya. ${ }^{5}$

Sedangkan pendekatan Aliran diperlukan karena tugas intelektual hari ini adalah mempelajari dan memahami Islam sebagai Aliran pemikiran yang membangkitkan kehidupan manusia, perseorangan maupun masyarakat, dan bahwa sebagai intelektual seseorang akan memikul amanah demi masa depan umat manusia yang lebih baik. Dengan kata lain Ali Syaria'ati mengajak kepada intelektual muslim dengan disiplin ilmu yang dimilikinya masing-masing agar digunakan untuk memahami ajaran Islam dengan berpedoman pada al-Qur'an dan al-Sunnah. ${ }^{6}$

Senada dengan Ali Syariati, Nasarudin Rozak juga menawarkan metode memahami Islam secara integral, menurutnya ada empat cara dalam memahami Islam, yaitu: Pertama, Islam harus dipelajari dari sumber asli yaitu al-
Qur'an dan al-hadits, kedua, Islam harus dipelajari secara integral, tidak dengan cara parsial, ketiga, Islam dipelajari dari kepustakaan yang ditulis para ulama besar, kaum zuama' dan sarjana-sarana islam, karena mereka semua dianggap memiliki pemahaman yang baik tentang Islam.keempat, Islam hendaknya dipelajari dari ketentuan normatif teologis yang ada dalam al-Qur'an, baru kemudian dhubungkan dengan kenyataan historis, empiris, dan sosiologis yang ada dimasyarakat. Dengan cara demikian dapat diketahui tingkat kesesuaian atau kesenjangan antara islam yang berada pada dataran normatif teologis yang ada dalam al-Qur'an dengan Islam yang ada pada dataran historis, empiris dan sosiologis. 7

Masih sepaham dengan pendapat diatas Syaikh Mahmood Shaltoot sebagaimana yang dikutip oleh Mukti Ali menyatakan bahwa Islam terdiri dua elemen, yaitu aqidah dan syari'ah. Lalu cara mendekatinya adalah dengan cara filosofis - doktriner. ${ }^{8}$ Istilah filosofis doktriner senada dengan pendekatan sintesis dari Mukti Ali yang juga senada dengan pendekatan pengkajian Islam yang dinamakan pendekatan Ilmiah - cum doktriner. Konsep tersebut muncul karena dilatarbelakangi adanya kesenjangan dalam memahami Islam antara Ahli ilmu 
pengetahuan termasuk di dalamnya para orientalis dengan para ulama'. Para ahli ilmu pengetahuan mendekati Islam dengan cara ilmiah saja, sedangkan para ulama' memahami Islam dengan cara doktriner dan dogmatis, yang sama sekali tidak dihubungkan dengan kenyataankenyataan hidup di dalam masyarakat. Sehingga muncul ide untuk menggabungkan metode tersebut supaya saling bersinergi untuk mendapatkan pemahaman Islam yang lebih sempurna. ${ }^{9}$

Metode yang digunakan oleh Mahmood Shalthoot ini bertentangan dengan kebanyakan ulama-ulama sebelumnya yang menyatakan bahwa Islam terdiri dari dari aqidah dan Mu'amalah, sedangkan mu'amalah ini dibagi dua, yaitu mu'amalah yang berhubungan dengan dengan Tuhan dan mu'amalah yang berhubungan dengan manusia. Pendekatan mereka adalah doktriner. 10

Pada abad 19 setelah berkembangnya metodologi ilmu-ilmu sosial dan ilmu agama, muncullah kajian agama yang bersifat empiris dimana kajian- kajian agama tersebut menggunakan pendekatan-pendekatan ataupun kerangka metodologis ilmu-ilmu sosial, seperti sosiologi, antropologi, maupun psikologi. Dalam konteks ini misalnya, secara sosiologis, agama dianggap sebagai bagian dari konstuksi realitas sosial; secara antropologi agama dipandang sebagai dipandang sebagai bagian dari sistm budaya masyarakat; sedangkan secara psikologis kesadaran agama tidak dapat dipisahkan dari sistem dan struktur individu. Dengan demikian, dilihat dari sisi ilmu-ilmu tersebut, semuanya boleh dikatakan merupakan paradigma studi agama yang bersifat empiris. ${ }^{11}$

Dalam perkembangannya Muhammad Arkoun mencoba menggugat kemapanan studi keislaman (klasik), dan menawarkan paradigma kajian agama yang lebih bercorak empiris. Menurutnya perlu pengembangan metode studi keislaman dengan menggunakan pendekatan empiris - historis, dalam arti pendekatan sosiologis - antropologispsikologis terhadap teks-teks dan naskahnaskah keagamaan pada abad-abad lampau. Hampir semua teks-teks studi keislaman, baik yang ditulis orientalis maupun non orientalis, mengikuti begitu saja pola dan cara berfikir abad pertengahan yang sudah berbeda jauh dari cara dan pola berfikir era sekarang. ${ }^{12}$

Selanjutnya, ketika melihat alQur'an sebagai sentral kajian - kajian keislaman, maka para ulama' membahas 
metode yang terbaik guna memahami atau menafsirkan ayat-ayat al-Qur'an. Jawaban yang disepakati adalah metode Ma'tsur, yakni menafsirkan ayat al-Qur'an dengan ayat al-Qur'an yang lain, dan dengan hadits-hadits nabi S.A.W, serta pendapat - pendapat sahabat beliau. ${ }^{13}$

Dalam konteks pendekatan dalam memahami al-Qur'an ini juga maka Fazlurrahman mempunyai empat metode yang terkenal yaitu: (a)Teori Pewahyuan dan ruang temporal; (b)Teori gerakan ganda (double movement); (c) Hermeneutika dan objectivitas sejarah; (d) Pendekatan tafsir tematis. ${ }^{14}$

Teori pewahyuan dan ruang temporal adalah suatu metode yang berusaha memahami al-Qur'an melalui sosio-historikal, dimana tidak hanya memperhatikan aspek asbabunnuzul saja tapi lebih dari itu merangkumi pemahaman pada konteks budaya arab secara keseluruhan. 15

Sedangkan teori gerakan ganda (double movement) yang dimaksud adalah dia berusaha memahami konteks historis dengan berusaha menjelaskan gerakan ganda, dimana dia menelusuri dari situasi sekarang kepada situasi ketika pewahyuan, kemudian dari lampau ke masa kini (dari konteks pewahyuan ke konteks kekinian). ${ }^{16}$
Kemudian yang dimaksud dengan metode Hermeneutika dan objectifitas sejarah adalah bagaimana dalam memahami al-Qur'an senantiasa berdasar pada keobyetifan dari sejarah. ${ }^{17}$

Dan Metode yang terakhir yang dianggap paling fenomenal adalah metode tafsir tematis, dimana dia berusaha untuk memadukan ayat-ayat dengan mengikuti tema - tema yang bertujuan untuk menggambarkan keterpaduan al-Qur'an dan pesan Tuhan kepada manusia.Menurutnya dengan menggunakan metode ini akan bisa menangkap wahyu tuhan secara terpadu, konsisten, dan koheren. ${ }^{18}$

Berbicara tentang persoalan Islam dikaitkan dengan tradisi, terdapat dua hal penting yang perlu dipikir ulang (rethought) menurut Charles J. Adams sebagaimana dikutip oleh Muhammad Latif Fauzi, yaitu Islam dan agama. ${ }^{19}$ Dua hal itu merupakan kata kunci yang menjadi kegelisahan akademik Adams sehingga ia berkeinginan menggagas sebuah formulasi pendekatan studi Islam yang tepat dalam mengkaji persoalan Islam, agama, dan tra disi. Persoalan yang pertama, Islam, berkenaan dengan betapa sulitnya membuat garis pemisah yang jelas antara mana wilayah yang Islami dan yang tidak. Banyak orang yang masih takut membuat 
penjelasan atau jawaban ketika ditanya tentang Islam, apalagi jika jawaban itu berbeda dan kontradiktif dari persepsi yang selama ini telah terbangun. Padahal, menurut Adams, mustahil menjelaskan dan menemukan pemahaman esensi Islam yang dapat mencapai kesepakatan universal. ${ }^{20}$

Dalam konteks ini, maka selain Islam harus dipahami-dalam perspektif sejarah-sebagai sesuatu yang selalu berubah (change) dan berkembang (evolve), generasi Muslim harus mampu pula merespon kenyataan dunia (vision of reality) dan makna kehidupan manusia (meaning of human life). ${ }^{21}$

Menurut Charles J. Adams terdapat dua pola pendekatan untuk mengkaji

Islam, yaitu pendekatan Normative dan pend ekatan Deskriptif.Tentu saja, dua pendekatan ini tidak muncul seketika. Adams menjelaskan bahwa dua pendekatan ini terilhami oleh realitas ketika seseorang mengkaji Islam (atau agama lainnya) dengan tujuan agar lebih kokoh keislaman dan kepercayaannya (proselytizing) pada satu sisi, dan pada sisi yang lain, ada yang didasarkan atas dorongan intelektual (intellectual curiosity) semata karena melihat adanya persoalan agama yang cukup kompleks dalam konteks sosial. 22

Pendekatan normatif. Pendekatan ini, oleh Adams diklasifikasi menjadi tiga bagian, yaitu:23

\section{Pendekatan missionaris tradisional}

Pada abad 19, terjadi gerakan misionaris besar-besaran yang dilakukan oleh gereja-gereja, aliran, dan sekte dalam Kristen. Gerakan ini menyertai dan sejalan dengan pertumbuhan kehidupan politik, ekonomi, dan militer di Eropa yang sangat berpengaruh terhadap kehidupan masyarakat di Asia dan Afrika. Sebagai konsekuensi logis dari gerakan itu, banyak misionaris dari kalangan Kristen yang pergi ke Asia dan Afrika mengikuti kolonial (penjajah) untuk merubah suatu komunitas masyarakat agar masuk agama Kristen serta meyakinkan masyarakat akan pentingnya peradaban Barat. Untuk mewujudkan tujuannya tersebut, para missionaris berusaha dengan sungguh untuk membangun dan menciptakan pola hubungan yang erat dan cair dengan masyarakat setempat. Begitu juga dengan penjajah, mereka harus mempelajari bahasa daerah setempat dan bahkan tidak jarang mereka terlibat dalam aktivitas kegiatan masyarakat yang bersifat kultural. Dengan demikian, eksistensi dua kelompok itu, 
missionaris tradisional dan penjajah (yang sama-sama beragama Kristen) mempunyai pengaruh yang sangat signifikan

terhadap perkembangan keilmuan Islam.

Dalam konteks itu-karena adanya relasi yang kuat antara Islam dan missionaris Kristen-, maka Charles J. Adams berpendapat bahwa studi Islam di Barat dapat dilakukan dengan memanfaatkan missionaris tradisional itu sebagai alat pendekatan yang efektif. Dan inilah yang kemudian disebut dengan pendekatan missionaris tradisional (traditional

missionaris approach) dalam studi Islam.

\section{Pendekatan apologetik}

Menurut Adams, pendekatan apologetik memberikan kontribusi yang positif dan cukup berarti terhadap generasi Islam dalam banyak hal. Sumbangsih yang terpenting adalah menjadikan generasi Islam kembali percaya diri dengan identitas keislamannya dan bangga terhadap warisan klasik. Dalam konteks pendekatan studi Islam, pendekatan apologetik mencoba menghadirkan Islam dalam bentuk yang baik. Sayangnya, pendekatan ini terkadang jatuh dalam kesalahan yang meniadakan unsur ilmu pengetahuan sama sekali. Secara teoritis, pendekatan apologetik dapat dimaknai 46 dalam tiga hal. Pertama, metode yang berusaha mempertahankan dan membenarkan kedudukan doktrinal melawan para pengecamnya. Kedua, dalam teologi, usaha membenarkan secara rasional asal muasal ilahi dari iman. Ketiga, apologetik dapat diartikan sebagai salah satu cabang teologi yang mempertahankan dan membenarkan dogma dengan argumen yang masuk akal. Ada yang mengatakan bahwa apologetika mempunyai kekurangan internal. Karena, di satu pihak, apologetik menekankan rasio, sementara di pihak lain, menyatakan dogma-dogma agama yang pokok dan tidak dapat ditangkap oleh rasio. Dengan kata lain, apologetik, rasional dalam bentuk, tetapi i rasional dalam isi.

\section{Pendekatan irenic}

Pendekatan ini lebih dilakukan dengan mempertunjukkan keindahan dan nilai religius yang menjiwai tradisi Islam, hal ini sebagai langkah menghilangkan prasangka, perlawanan, dan hinaan yang dilakukan oleh barat, khususnya Kristen Barat, terhadap Islam. Oleh karena itu, langkah praktis yang dilakukan adalah membangun dialog antara umat Islam dengan kaum Kristen untuk membangun jembatan penghubung yang saling menguntungkan antara tradisi kegamaan dan bangsa. 
Usaha ini pernah dilakukan oleh uskup Kenneth Gragg, seorang yang mumpuni dalam kajian Arab dan teologi. Melalui beberapa seri tulisannya yang cukup elegan dan dengan gaya bahasa yang puitis, ia telah cukup berhasil menunjukkan kepada Barat secara umum dan kaum Kristen secara khusus tentang adanya keindahan dan nilai religius yang menjiwai tradisi Islam.

Sedangkan dalam pendekatan yang bersifat deskriptif, Adams membagi ke dalam tiga komponen, yaitu:24

\section{Pendekatan filologis dan sejarah}

Filologi berguna untuk meneliti bahasa, meneliti kajian linguistik, makna kata-kata dan ungkapan terhadap karya sastra Hasil dari pendekatann filologis, menurut Adams, adalah sebuah sumber pustaka (literatur) yang dapat menyentuh semua aspek kehidupan dan kesalihan umat Islam. Tidak hanya menjadi rujukan pengetahun Barat tentang Islam dan sejarahnya, filologis juga memainkan peranan penting di dunia Islam. Outcome dari pendekatan filologis dan historis ini sebagian besar telah dimanfaatkan oleh para intelektual, politisi, dan sebagainya. Selain itu, filologi harus turut andil dalam studi Islam. Hal terpenting yang dimiliki oleh mahasiswa Muslim adalah kekayaan literatur klasik seperti sejarah, teologi, dan mistisisme. yang kesemuanya tidak mungkin dipahami tanpa bantuan filologi.

Penelitian agama dengan menggunakan pendekatan filologi dapat dibagi dalam tiga pendekatan, yaitu tafsir, content analysis, dan hermeneutika. Ketiga pendekatan tersebut tidak terpisah secara ekstrim. Pendekatan-pendekatan itu bisa over lapping, saling melengkapi, atau bahkan dalam sudut tertentu sama..

Sedangkan sejarah atau historis merupakan ilmu yang di dalamnya dibahas berbagai peristiwa dengan memperhatikan unsur tempat, waktu, obyek, latar belakang, dan pelaku dari peristiwa tersebut. Melalui pendekatan sejarah seseorang diajak menukik dari alam idealis ke alam yang bersifat empiris dan mendunia. Dari keadaan ini seseorang akan melihat adanya kesenjangan atau keselarasan antara yang terdapat dalam alam idealis dengan yang ada di alam empiris dan historis.

Ada dua unsur pokok yang dihasilkan oleh analisis sejarah. Pertama, kegunaan dari konsep periodesasi dan derivasi darinya. Kedua, rekonstruksi proses genesis, perubahan, dan perkembangan.dengan analisis ini, manusia dapat dipahami secara kesejarahan. 


\section{Pendekatan ilmu-ilmu sosial}

Sangat sulit untuk mendefinisikan apa yang disebut dengan "pendekatan ilmu sosial" terhadap studi agama terutama semenjak terdapat banyak pendapat di kalangan ilmuwan tentang alam dan validitas studi yang mereka gunakan.

Dalam wilayah studi agama, usaha yang ditempuh oleh pakar ilmu sosial adalah memahami agama secara objektif dan peranannya dalam kehidupan masyarakat. Tujuannya agar dapat menemukan aspek empirik dari keberagamaan berdasarkan keyakinan bahwa dengan membongkar sisi empirik dari agama itu akan membawa seseorang kepada agama yang lebih sesuai dengan realitasnya, profan (membumi). Walaupun ilmu ini juga mempunyai kekurangan, yaitu melakukan reduksi pemahaman seseorang terhadap agama.

\section{Pendekatan fenomenologis}

Terdapat dua hal penting yang mencirikan pendekatan fenomenologi agama. Pertama, fenomenologi adalah metode untuk memahami agama sesorang yang termasuk di dalamnya usaha sebagian sarjana dalam mengkaji pilihan dan komitmen mereka secara netral sebagai persiapan untuk melakukan rekonstruksi pengalaman orang lain. Kedua, konstruksi skema taksonomik untuk mengklasifikasi fenomena dibenturkan dengan batas-batas budaya dan kelompok religius. Secara umum, pendekatan ini hanya menangkap sisi pengalaman keagamaan dan kesamaan reaksi keberagamaan semua manusia secara sama, tanpa memperhatikan dimensi ruang dan waktu dan perbedaan budaya masyarakat.

Jika fenomenologi digunakan dalam mengkaji Islam berarati seorang peniliti memahami dan menganalisi Islam bukan atas dasar nilai-nilai yang tertuang dalam teks yang bersifat normatif, namun bagaimana seorang peneliti memahami islam berdasarkan apa yang dipahami dan diamalkan oleh umatnya. ${ }^{25}$

Arah dari pendekatan fenomenologi adalah memberikan penjelasan makna secara jelas tentang apa yang yang disebut dengan ritual dan upacara keagamaan, doktrin, reaksi sosial terhdap pelaku "drama" keagamaan. Sebagai sebuah ilmu yang relatif kebenarannya, pendekatan ini tidak dapat berjalan sendiri. Secara operasioonal, ia membutuhkan perangkat lain, misalnya sejarah, filologi, arkeologi, studi literatur, psikologi, sosiologi, antropologi, dan seba gainya. ${ }^{26}$ 


\section{Pemikiran Harun Nasution tentang} Aspek Ibadat ,Latihan Spritual dan Ajaran Moral

Manusia dalam faham Islam, sebagai halnya dalam agama monoteisme lainnya, tersusun dari dua unsur, unsur jasmani dan unsur rohani . Tubuh manusia berasal dari materi dan mempunyai kebutuhan-kebutuhan materiil, sedangkan roh manusia bersifat Immateri dan mempunyai kebutuhan spritual. Badan, karena mempunyai hawa nafsu, bisa membawa pada kejahatan, sedangkan roh, karena berasal dari unsur yang suci, mengajak kepada kesucian. Kalau seseorang mementingkan hidup kematerian ia mudah sekali dibawa hanyut oleh kehidupan yang tidak bersih, bahkan dapat dibawa hanyut kepada kejahatan.

Oleh karena itu pendidikan jasmani manusia harus disempurnakan dengan pendidikan rohani. Pengembangan dayadaya jasmani sesorang tanpa dilengkapi dengan pengembangan daya rohani akan membuat hidupnya berat sebelah dan kehilangan keseimbangan. Orang yang demikian akan menghadapi kesulitankesulitan dalam hidup duniawi, apalagi kalau hal itu membawa kepada perbuatan - perbuatan tidak baik dan kejahatan. Ia akan merupakan manusia yang merugikan, bahkan manusia yang membawa kerusakan bagi masyarakat . Selanjutnya ia akan kehilangan hidup bahagia di akhirat dan akan menghadapi hidup kesengsaraan di sana. Oleh karena itu amatlah penting supaya roh yang ada dalam diri manusia mendapat latihan, sebagaimana badan manusia juga mendapat latihan.

Dalam Islam ibadatlah yang memberikan latihan rohani yang diperlukan manusia. Semua ibadat yang ada dalam Islam, salat, puasa, haji dan zakat, bertujuan membuat roh manusia supaya senantiasa tidak lupa pada Tuhan, bahkan senantiasa dekat pada-Nya. Keadaan senantiasa dekat pada Tuhan sebagai Zat Yang Maha Suci dapat mempertajam rasa kesucian seseorang. Rasa kesucian yang kuat akan dapat menjadi rem bagi hawa nafsu untuk melanggar nilai-nilai moral, peraturan dan hukum yang berlaku dalam memenuhi keinginannya.

Di antara ibadat Islam, salatlah yang membawa manusia terdekat kepada Tuhan. Di dalamnya terdapat dialog antara manusia dengan Tuhan dan dialog berlaku antara dua pihak yang saling berhadapan. Dalam salat manusia memang berhadapan dengan Tuhan. Dalam Sholat seseorang melakukan hal- 
hal berikut: menuju ke - Maha Sucian Tuhan, menyerahkan diri kepada Tuhan, memohon supaya dilindungi dari godaan syetan, memohon diberi petunjuk kepada jalan yang benar dan dijauhkan dari kesesatan dan perbuatan-perbuatan yang tidak baik, perbuatan-perbuatan jahat dan sebagainya. Pendek kata dalam dialog dengan Tuhan itu seseorang meminta supaya rohnya disucikan. Dialog ini wajib diadakan lima kali sehari, dan kalau seseorang lima kali sehari dengan sadar memohon penyucian roh, dan ia memang berusaha ke arah yang demikian, rohnya akan dapat menjadi bersih dan ia akan dijauhkan dari perbuatan-perbuatan yang tidak baik, apalagi dari perbuatanperbuatan jahat.

Puasa juga merupakan penyujian roh. Di dalam berpuasa seseorang harus menahan hawa nafsu makan, minum dan seks. Di samping itu ia juga harus menahan rasa amarah, keinginan mengatai orang, bertengkar dan perbuatan-perbuatan kurang baik lainnya. Latihan jasmani dan rohani di sini bersatu dalam usaha menyucikan roh manusia. Di bulan puasa dianjurkan pula supaya orang banyak bersalat dan membaca alQur'an, yaitu hal-hal yang membawa orang dekat kepada Tuhan. Latihan ini disempurnakan dengan pernyataan rasa kasih kepada anggota masyarakat yang 50 lemah kedudukan ekonominya dengan mengeluarkan zakat fitrah bagi mereka.

Ibadah haji juga merupakan penyucian roh. Dalam mengerjakan haji di Mekkah, orang berkunjung ke Baitullah (Rumah Tuhan dalam arti rumah peribadatan yang pertama di dirikan atas perintah Tuhan di dunia ini). Sebagaimana sholat, orang disini juga merasa dekat sekali dengan Tuhan. Bacaan-bacaan yang diucapkan sewaktu mengerjakan haji itu merupakan dialog antara manusia dan dengan Tuhan. Usaha penyucian Roh di sini disertai oleh latihan jasmani dalam bentuk pakaian, makanan dan tempat tinggal sederhana. Selama mengerjakan haji perbuatan-perbuatan tidak baik harus dijauhi. Di dalam haji juga terdapat pula latihan rasa bersaudara antara semua manusia, tiada beda antara kaya dan miskin, raja dan rakyat biasa, antara besar dan kecil, semua sederajat.

Zakat, sungguhpun itu mengambil bentuk mengeluarkan sebagian dari harta untuk menolong fakir miskin dan sebagainya juga merupakan penyucian roh. Disini dilatih menjauhi kerakusan pada harta dan memupuk rasa bersaudara, rasa kasihan dan suka menolong anggota masyarakat yang berada dalam kekurangan.

Ibadat dalam arti Islam sebenarnya bukan bertujuan supaya Tuhan disembah 


\section{Khoiruman \\ ASPEK IBADAH, LATIHAN SPRIIIUAL DAN AJARAN MDRAL}

dalam arti penyembahan yang terdapat dalam agama-agama primitif. Pengertian serupa ini adalah pengertian yang tidak tepat. Betul ayat 56 dari surat al-Zariat mengatakan:

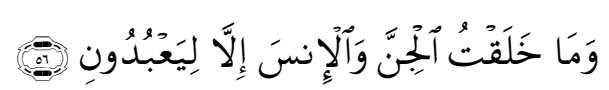

Dan ini diartikan bahwa manusia diciptakan semata-mata untuk beribadat kepada tuhan yaitu mengerjakan salat, puasa, haji, dan zakat. Soal ibadat memang amat penting artinya dalam ajaran Islam. Tapi mestikah kata " liya'budun " di sini berarti ibadat, mengabdi atau menyembah? Sebenarnya Tuhan tidak berhajat untuk disembah atau dipuja manusia. Tuhan adalah Maha Sempurna dan tak berhajat kepada apapun. Oleh karena itu kata " liya'budun" di sini lebih tepat kalau diberi arti lain daripada arti beribadat, mengabdi, memuja, apalagi menyembah. Lebih tepat kalau kata itu diberi arti tunduk dan patuh dan kata "'abada "memang mengadung arti tunduk dan patuh sehingga ayat itu menjadi:

" Tidaklah aku ciptakan jin dan manusia kecuali untuk tunduk dan patuh kepada-Ku".

Arti ini lebih sesuai dengan arti yang terkandung dalam kata muslim dan muttaqi, yaitu menyerah, tunduk dan menjaga diri dari hukuman Tuhan di Hari Kiamat dengan mematuhi perintahperintah dan larangan-larangan Tuhan. Dengan lain kata, manusia diciptakan Tuhan sebenarnya ialah untuk berbuat baik dan tidak untuk berbuat jahat, sungguhpun di dunia ada manusia yang memilih kejahatan.

Selanjutnya arti sembah dan sembahyang yang diberikan kepada " 'abada "dan" sholaa " juga membawa paham yang tidak tepat. Kata sembahyang berasal dari suatu bahasa yang memakai falsafah lain dari falsafah Islam. Sembahyang mengandung arti menyembah kekuatan gaib dalam paham masyarakat animisme dan politeisme. Dalam falsafah masyarakat serupa ini kekuatan gaib yang demikian ditakuti dan mesti disembah dan diberi sesajen agar ia jangan murka dan jangan membawa bencana bagi alam.

$$
\text { Kata sembahyang yang }
$$
mengandung arti demikian, ketika dibawa ke dalam konteks Islam, sebagai terjemahan bagi kata "'abada "dan " shola", menimbulkan perubahan dalam konsep Tuhan yang ada dalam Islam. Dalam Islam Tuhan bukanlah merupakan suatu zat yang ditakuti tetapi suatu zat yang dikasihi. Ini ternyata dari ucapan " bismillahirrahmanirrahim " yang tiap hari 
berkali-kali dibaca umat Islam. Rahman dan Rahim berarti pengasih dan Penyayang, jadi bukanTuhan yang ditakuti, tetapi Tuhan yang dikasihi manusia.

Tetapi kata sembahyang yang masuk ke dalam konteks Islam itu menghilangkan sifat pengasih dan penyayang itu dari kesadaran kita umat Islam. Inilah pula kelihatan salah satu sebabnya maka "dalam al-Qur'an di Indonesia akan menjadi " takutilah Tuhan" sedang arti sebenarnya adalah " pelihara dan jagalah dirimu dari hukum Tuhan di Akhirat dan patuhlah kepada perintah dan larangan-Nya".

Tujuan ibadat dalam Islam bukanlah menyembah, tetapi mendekatkan diri kepada Tuhan, agar demikian roh manusia senantiasa diingatkan kepada hal-hal yang bersih lagi suci, sehingga akhirnya rasa kesucian seseorang menjadi kuat dan tajam. Roh yang suci membawa kepada budi pekerti baik dan luhur. Oleh karena itu, ibadat disamping merupakan latihan spritual, juga merupakan latihan moral.

Salat memang erat hubungannya dengan latihan moral. Ayat 45 dari Surat al-Ankabut menyatakan:

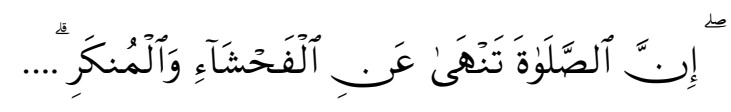

"Sesungguhnya shalat itu mencegah dari (perbuatan- perbuatan) keji dan mungkar."

Dalam satu hadits qudsi juga dinyatakan bahwa Tuhan akan menerima salat orang yang merendah diri tidak sombong, tidak menentang malahan selalu ingat kepada Tuhan dan suka menolong orang-orang yang dalam kesusasahan seperti fakir miskin, orang yang dalam perjalanan, janda dan orang kena bencana. Jadinya salah satu tujuan salat adalah menjauhkan manusia dari perbuatan-perbuatan jahat dan mendorongnya untuk berbuat hal-hal yang baik.

Demikian juga puasa dekat hubungannya dengan latihan moral. Ayat 183 dari surat al-Baqarah mengatakan:

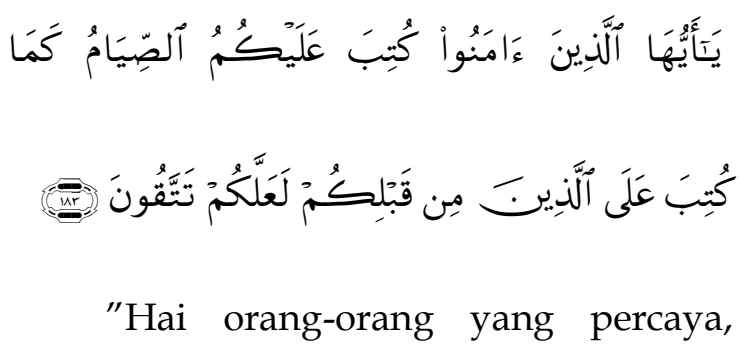
diwajibkan atas kamu berpuasa sebagaimana diwajibkan atas orang-orang sebelum kamu agar kamu bertakwa. "

Bertaqwa artinya menjauhi perbuatan-perbuatan jahat dan melakukan perbuatan-perbuatan baik. Hadits-hadits Nabi juga mengaitkan puasa dengan perbuatan-perbuatan tidak baik. 
Jadi puasa yang tidak menjauhkan manusia dari ucapan dan perbuatan tidak baik tidak ada gunanya. Orang yang demikian tidak perlu menahan diri dari makan dan minum, karena puasanya tidak berguna. Artinya puasa bukanlah menahan dari dari makan dan minum, tetapi menahan diri dari ucapan-ucapan tidak baik lagi kotor.

Kemudian mengenai haji, ayat 197 dari surat al-Baqarah:27

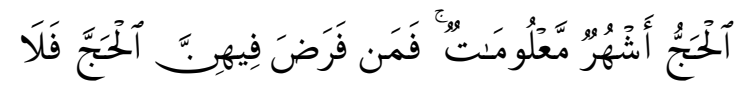

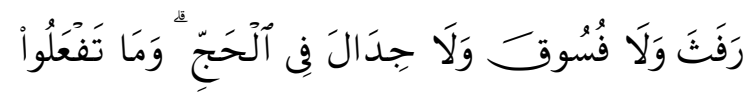

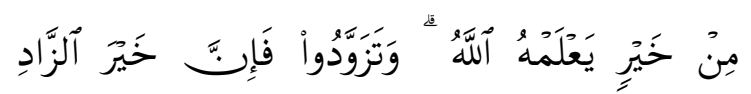

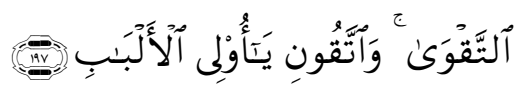

Ayat tersebut diatas menerangkan bahwa sewaktu mengerjakan haji orang tidak boleh mengeluarkan ucapan tidak senonoh, tidak boleh berbuat hal-hal tidak baik dan tidak boleh bertengkar.

Tentang zakat ayat 103 dari surat al-Taubah: ${ }^{28}$

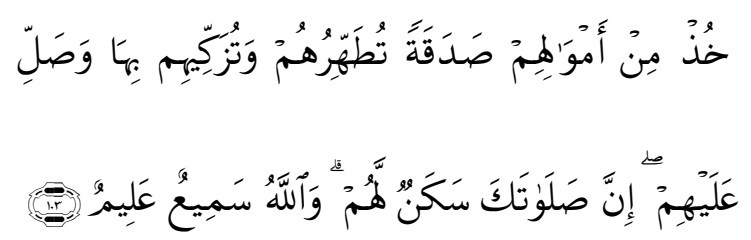

Ayat tersebut menjelaskan bahwa zakat diambil dari harta untuk membersihkan dan menyucikan pemiliknya. Hal tersebut dipertegas dengan sabda rasulullah yang menjelaskan bahwa arti sedekah luas sekali, sehingga ia mencakupi senyuman kepada manusia, seruan pada perbuatan baik dan larangan dari perbuatan jahat, memberi petunjuk kepada manusia, menjauhkan duri dari jalan, memberi air yang ada digayung kita kepada orang yang berhajat dan menuntun orang yang lemah penglihatannya.

Bahwa semua ibadat itu dekat hubungannya dengan pendidikan moral dijelaskan lebih lanjut oleh salah satu hadits yang menyatakan bahwa orang yang kuat sembahyang, berpuasa dan bersedekah, tetapi lidahnya menyakiti tetangga, akan masuk neraka. Dan orang yang sedikit menjalankan ibadat sembahyang, puasa, dan sedekah, tetapi tidak menyakiti hati tetangga akan masuk surga. Dalam hadits lain juga mengatakan bahwa orang yang berdusta, tidak menepati janji dan berkhianat, adalah munafiq, sungguhpun ia mengaku dirinya orang Islam, berpuasa, mengerjakan sholat, haji, umrah, menurut hadits berikut. Dalam hadits lain juga juga diterangkan oleh Nabi tentang ada hal yang lebih tinggi, derajatnya dari salat, puasa dan sedekah. Ketika para sahabat 
ingin mengetahui hal itu, maka Nabi menjawab: Memperbaiki persahabatan. Selanjutnya juga nabi menjelaskan bahwa sifat pemurah membuat orang dekat pada tuhan dan surga, sedang sifat bakhil membuat orang jauh dari Tuhan dan surga. Dan begitunya sifat pemurah sehingga orang jahil tetapi pemurah lebih dikasihi Tuhan dari orang banyak beribadat tapi bakhil.

Demikianlah al-Qur'an dan alHadits menjelaskan bahwa ibadat sebenarnya merupakan latihan spritual dan moral dalam usaha Islam membina manusia yang tidak kehilangan keseimbangan hidup, lagi berbudi pekerti luhur.

Disamping latihan spritual dan moral ini, al-Qur'an dan al-Hadits juga membawa ajaran-ajaran atau normanorma yang harus dilaksanakan dan dipegang oleh setiap orang muslim, sebagaimana dalam surat al-Nisa' ayat 58 yang mengajarkan supaya manusia mengetahui hak orang lain dan bersikap ikhlas terhadap hak itu. Ayat ini memerintahkan supaya amanat (hak yang dipercayakan kepada seseorang) diteruskan kepada yang berhak, disamping ayat ini juga mengajarkan supaya manusia bersikap adil.

Selain ajaran - ajaran moral tentang berbuat amanat dan adil al54
Qur'an juga mengajak berbuat baik kepada orang lain dan keluarga(al-Nahl 90), menganjurkan untuk berkata baik (Surat Ibrahim ayat 24, 25, dan 26), melarang untuk mencemooh orang lain, karena mungkin lebih baik dari kita sendiri. Melarang untuk berburuk sangka, karena sebagiannya adalah merupakan dosa, dan mencari kesalahan-kesalahan orang lain (Surat Hujurat 11-12).

Selain ajaran Akhlaq al-Qur'an juga mengandung ajaran-ajaran bagaimana seharusnya tingkah laku seseorang dalam hidup sehari-hari. Misalnya agar seseorang jangan memasuki rumah orang lain sebelum minta izin (al-Nur ayat 27-28), meminta izin terlebih dahulu sebelum memasuki ruang tertutup dengan mengetok pintu tiga kali meskipun anak yang belum dewasa (al-Nur ayat 58).

Ajaran-ajaran moral dalam alqur'an ini dipertegas juga oleh sabdasabda Nabi, bagaimana Nabi bersabda tentang manfaat kejujuran yang membawa kedamaian, dan dusta membawa kecemasan, Rasul juga menjelaskan orang yang kuat adalah orang yang bisa menahan amarahnya, Rasul juga mengajak untuk berlemah lembut.terhadap orang yang tidak menghargainya, memaafkan orang yang tak memberi apa-apa, tetap bersahabat 
dengan orang yang memutus tali shilaturrahim. Hal inilah yang menyebabkan Rasul dipuji dalam alqur'an sebagai orang yang mempunyai akhlaq yang luhur.

Dari paparan diatas bisa dikatakan bahwa intisari ajaran Islam adalah berkisar soal baik dan buruk. Inilah yang menyebabkan para teolog berbeda pendapat tentang masalah baik dan buruk - perbedaaan itu seputar "Dapatkah manusia melalui akalnya mengetahui perbuatan mana yang buruk? Atau untuk mengetahui itu, manusia perlu pada wahyu?pertentangan ini misalnya terjadi pada aliran Asy'ariah dan Mu'tazilah.

Disamping masalah baik buruk ini dibahas dalam teologi Islam, fikih atau hukum Islam sebenarnya juga memusatkan pembahasan pada soal baik dan buruk itu. Pengertian wajib, haram, sunnah, dan makruh hubungannya erat sekali dengan perbuatan baik dan buruk itu. Pada dasarnya perbuatan buruk atau jahat ada yang haram untuk dikerjakan dan ada yang makruh yang berakibat kemudharatan dan kesengsaraan jika dilaksanakan, sedangkan perbuatan baik ada yang wajib dan ada yang sunnah yang berakibat dan kebahagiaan jika dilaksanakan.
Ancaman yang berupa neraka dan janji yang berupa surga diakhirat, juga erat hubungannya dengan soal baik dan buruk ini.Orang yang berbuat baik di dunia akan masuk surga di akhirat. Dan orang yang berbuat jahat akan masuk neraka.

Jelaslah, bahwa soal baik dan buruk, disamping soal ketuhanan menjadi dasar agama yang penting. Ini demikian, karena yang ingin dibina Islam ialah manusia baik yang yang menjauhi perbuatan buruk atau jahat di dunia. Manusia serupa inilah sebenarnya yang dimaksud dengan mukmin, muslim, dan Muttaqi (orang yang bertaqwa). Mukmin ialah orang yang percaya kepada Tuhan Yang Maha Esa, sebagai sumber-sumber yang bersifat absolut, muslim orang yang menyerahkan diri dan Tunduk kepada Tuhan dan muttaqi adalah orang yang memelihara diri dari hukuman Tuhan di akhirat, yaitu orang yang menjalankan perintah-perintah-Nya dan menjauhi larangan-larangan-Nya.

Dalam al-Qur'an kata muttaqin dalam al-qur'an memang dihubungkan dengan nilai-nilai seperti suka menolong, sungguhpun dalam keadaan kekurangan, dapat menahan amarah, suka memberi maaf kepada orang lain, menepati janji, sabar, tawadhu, suka kepada kebaikan 
dan benci pada kejahatan, berbuat baik kepada orang lain, jujur, suka pada kebenaran dan sebagainya. Kata muttaqin dalam al-qur'an selanjutnya dikontraskan dengan orang yang berbuat onar dan kacau dalam masyarakat, orang yang berbuat buruk, orang yang berdusta, orang yang bersikap zalim, penjahat, amoral dan sebagainya.

Dengan demikian, yang dimaksud dengan mukmin, muslim dan muttaqin sebenarnya adalah orang yang bermoral tinggi dan berbudi pekerti luhur. Tidak heran kalau soal akhlak dan budi pekerti luhur memang merupakan ajaran yang penting sekali dalam Islam. Dan soal itu demikian pentingnya sehingga, bukan hanya ibadat salat, puasa, zakat serta haji saja, tetapi juga hukum fikih dan konsep iman,Islam, serta neraka, kesemuanya sebagaimana dilihat di atas erat hubungannya dengan perbuatan baik dan perbuatan buruk manusia. Tujuan dasar dari semua ajaran-ajaran Islam memanglah untuk mencegah manusia dari perbuatan buruk atau jahat dan selanjutnyauntuk mendorong manusia kepada perbuatan-perbuatan baik. Dari manusia-manusia baik dan berbudi pekerti luhurlah masyarakat baik dapat terwujud.

\section{Analisis Pemikiran Harun Nasution} Tentang "Aspek Ibadat, Latihan spritual

\section{Dan Ajaran Moral"}

Setelah diperhatikan dengan seksama, pemikiran Harun Nasution dengan Tema" Aspek Ibadat, Latihan Spritual Dan Ajaran Moral" adalah berbicara tentang keterkaitan pokokpokok ajaran Islam yang berupa Akidah, Syari'ah, dan Akhlak. Dan pendekatan yang digunakan adalah pendekatan doktriner Filosofis (meminjam istilah Mahmood Syaltoot), atau kalau dalam bahasa Mukti ali metode sintesis dan dalam bahasa lainnya pendekatan IlmiahCum-doktriner.Hal ini senada dengan pendekatan Normatif Apologetik yang disampaikan oleh Charles J. Adams. Disamping itu juga Harun Nasution juga menggunakan penelitian Ekploratif Deskriptif dengan menggunakan pendekatan kesejarahan. Dan bisa diketahui juga bahwa dia menggunakan metode Komperasi (perbandingan) dan pendekatan Aliran (meminjam istilah Ali syari' ati).

Pendekatan filosofis doktriner/ Sintesis/Ilmiah-Cum-doktriner adalah pendekatan kajian yang berusaha suatu pendekatan memahami Islam yang tidak hanya menggunakan metode ilmiah saja yang menggunakan dimensi masalah kehidupan manusia di bumi (ilmu-ilmu manusia, historis dan sosiologis) saja, 
tetapi berusaha menggabungkan dengan sumber-sumber ajaran Islam yang utama yang mempunyai sifat dogmatis. Hal ini bisa terlihat dalam paparannya mengenai keterkaitan antara Ibadat, latihan spritual dan ajaran Moral (penulis;Ibadah, akidah, Syari'ah), dia senantiasa mendasarkan keterangannya dengan dalil-dalil yang bersumber dari al-Qur'an dan al-Hadits disamping dia juga menjelaskan dengan alasan filosofisnya. Contoh ketika dia menjelaskan tentang sholat, puasa, haji, dan zakat. Maka pendekatan filosofisnya (kaitannya dengan ilmu sosial) terlihat ketika menggambarkan bahwa ibadahibadah tersebut bisa menjadi latihan rohani/spritual dengan kata lain menguatkan akidah disamping latihan Moral yang berarti memperbaiki akhlaq manusia. Artinya ibadah - ibadah tersebut bisa memperbaiki hubungan manusia dengan Allah dan hubungan manusia dengan sesama manusia. Sedangkan pendekatan doktrinernya terlihat ketika menjelaskan masalah masalah ibadah diatas, dia senantiasa menyebutkan dasar hukumnya yang bersumber dari al-Qur'an dan hadits, misalnya dia menyebutkan bahwa alQur'an mendidik manusia yang sudah sholat agar bisa mencegah perbuatan keji dan munkar, karena itu bagian dari hakikat sholat. Pendekatan doktriner ini senada dengan pendekatan Normatif Apologetik, yang berusaha mencarikan alasan nash-nash dalam membuktikan kebenaran ajarannya.

Selanjutnya penilitian Eksploratif, Deskriptif dengan pendekatan kesejarahan adalah sebuah penilitian yang mencoba menggambarkan keadaan suatu obyek, kemudian mencoba untuk memperbaiki dan mengembangkan obyek tersebut supaya menjadi sesuatu yang sempurna, dengan tetap melihat konteks kesejarahan dari setiap obyek. Pendekatan ini terlihat terlihat ketika dia berusaha merubah pemahaman konsep tentang istilah Ibadah, Sembahyang, yang sudah dipahami kebanyakan masyarakat dengan melihat konteks kesejarahan. Contoh , kata sembahyang yang diberikan pada kata “ Sembah "dan "Hyang" menurutnya tidak tepat, karena sembahyang mempunyai arti menyembah kekuatan gaib dalam paham masyrakat animisme dan politeisme. Dalam falsafah masyarakat ini kekuatan gaib yang demikian ditakuti dan mesti disembah dan diberi sesajen supaya dia tidak marah dan jangan membawa bencana pada alam. Menurutnya kata sembahyang yang mengandung arti demikian, ketika dibawah ke konteks Islam sebagai 
terjemahan bagi kata " Sembah “dan

“ Hyang ", menimbulkan perubahan dalam konsep Tuhan yang ada dalam islam. Dalam Islam Tuhan bukanlah zat yang ditakuti tetapi suatu zat yang dikasihi.

Pendekatan metode Komperasi (perbandingan) dan pendekatan Aliran sangat terlihat ketika dia membandingkan pendapat para teolog tentang konsep baik dan buruk yang dalam paparannya membandingakan pendapat paham Asy'ariah dan mu'tazilah.

Walhasil, menurut penulis pendekatan yang dilakukan Harun Nasution dalam mengkaji aspek Ibadat, Latihan Spritual, dan Ajaran moral adalah sudah sesuai dengan yang tema yang disajikan. Meskipun pendekatan yang dilakukan terkesan bervariasi, ternyata bukan berarti inkonsistensi beliau dalam membahas masalah tersebut. Justru dengan variatifnya pendekatan menceminkan keluasan dan keluesan ilmu pengetahuannya terhadap tema tersebut. Penulis sendiri sepakat dengan banyaknya pendekatan yang digunakan selama bertujuan untuk lebih memudahkan pemahaman pembaca tentang topik yang dikaji.

\section{E. Kesimpulan}

Dari paparan Harun Nasution tentang Topik Aspek Ibadat, Latihan Spritual, dan Ajaran Moral (keterkaitan pokok-pokok ajaran Islam) bisa disimpulkan bahwa telah terjadi kesalahan pendekatan bagi sesorang yang memahami pokok-pokok ajaran islam secara parsial. Hal ini dibuktikan oleh keterangan Harun Nasution, bahwa Idealnya pokok-pokok ajaran Islam(Akidah, Syari'ah, dan Akhlaq) itu harus dipahami dan dilaksanakan secara integral untuk menuju kepada kesempurnaan manusia (insan kamil), karena pada hakekatnya manusia itu harus senantiasa meningkatkan hubungan baiknya dengan Allah dan hubungan baiknya dengan sesama manusia dan alam semesta. Dengan kata lain Bagaimana dalam kehidupan beragama seseorang bisa mencegah dirinya untuk berbuat buruk dan jahat, dan kemudian mendorongnya untuk berbuat baik.

Kajian ini sangat dibutuhkan oleh umat Islam yang kebanyakan belum sempurna (kaffah) dalam memahami dan melaksanakan pokok-pokok ajaran Islam secara integral. Untuk itu perlu dikembangkan dan disosialisasikan kajian-kajian serupa dengan pendekatan pendekatan doktriner filosofis, dengan harapan semoga bisa meningkatkan 
kesadaran dan pemahaman umat Islam dalam mengamalkan ajaran-ajaran Islam menuju umat yang diridhoi Allah.

\section{Referensi}

1http:/ / www.academia.edu/35323925/._ Harun_Nasution_biografi_pemikiran_dan_tipologi diakses 12 Februari 2019

2https://id.wikipedia.org/wiki/Harun_N asution, diakses pada 25 April 2019

${ }^{3}$ Abudin Nata, Metodologi Studi Islam,(Jakarta: PT. Raja Grafindo Persada, 2008) h. 206-207

${ }^{4}$ Abudin Nata, Metodologi Studi Islam, h. 305

${ }^{5}$ Abudin Nata, Metodologi Studi Islam, h. 152-153

${ }^{6}$ Abudin Nata, Metodologi Studi Islam, h. 154

${ }^{7}$ Abudin Nata, Metodologi Studi Islam, $h$. 155-157

8A. Mukti Ali, "Metodologi Ilmu Agama", dalam Buku Metodologi Penilitian Agama, (Yogyakarta: Tiara Wacana, 1990), Cet. 2, h. 41. menurut penulis metode filosofis - doktriner adalah suatu pendekatan memahami Islam yang tidak hanya menggunakan metode ilmiah saja yang menggunakan dimensi masalah kehidupan manusia di bumi (ilmu-ilmu manusia, historis dan sosiologis) saja, tetapi berusaha menggabungkan dengan sumber-sumber ajaran Islam yang utama yang mempunyai sifat dogmatis.

${ }^{9}$ A. Mukti Ali, "Metodologi Ilmu Agama", h. $45-46$.

10A. Mukti Ali, Metodologi Ilmu Agama, h. 41. Menurut penulis metode doktrineradalah metode pendekatan dalam memahami ajaran Islam berdasarkan teks-teks sumber utama ajaran Islam, yaitu al-Qur'an dan al-Hadits saja tanpa menggabungkan dengan pendekatan dimensi dimensi lain yang melingkupi manusia.

11M. Deden Ridwan, Tradisi Penelitian Agama Islam, (Bandung: Yayasan Nuansa Cendekia, 2001),h. 15-16.

12M. Deden Ridwan, Tradisi Penelitian Agama Islam, h. 16.
13Muhammad Qurais Shihab, "Posisi Sentral al-Qur'an Dalam Studi al-Qur'an," dalam Metodologi Penelitian Agama, h. 136-137

14Muhamed Imran Muhammad Taeb, Fazlur Rahman (1919-1998) Printis tafsir Kontekstual, Melalui <http: / www. imran@thereadinggroup, sg $\quad(7 / 01 / 2010)$, h. 4-5

15Muhamed Imran Muhammad Taeb, Fazlur Rahman (1919-1998) Printis tafsir Kontekstual, h. 5

16Disarikan dari Muhamed Imran Muhammad Taeb, Fazlur Rahman (1919-1998) Printis tafsir Kontekstual, h. 8-10

17Disarikan dari Muhamed Imran Muhammad Taeb, Fazlur Rahman (1919-1998) Printis tafsir Kontekstual, h. 12-14

18Disarikan dari Muhamed Imran Muhammad Taeb, Fazlur Rahman (1919-1998) Printis tafsir Kontekstual, h. 14-15

19Muhammad Latif Fauzi, Pendekatan Normatif dan Deskriptif dalam Studi Islam (Telaah atas Karya Charles J. Adams) Melalui <http: / cfis.uii, ac.id/indeks. php (7 / 01/ 2010)

20Muhammad Latif Fauzi, Pendekatan Normatif dan Deskriptif dalam Studi Islam (Telaah atas Karya Charles J. Adams) Melalui <http: / cfis.uii, ac.id/indeks. php (7 / 01/ 2010).

${ }^{21}$ Muhammad Latif Fauzi, Pendekatan Normatif dan Deskriptif dalam Studi Islam (Telaah atas Karya Charles J. Adams) Melalui <http: / cfis.uii, ac.id/indeks. php (7 / 01/ 2010)

22Muhammad Latif Fauzi, Pendekatan Normatif dan Deskriptif dalam Studi Islam (Telaah atas Karya Charles J. Adams) Melalui <http: / cfis.uii, ac.id/indeks. php (7 / 01/ 2010)

${ }^{23}$ Muhammad Latif Fauzi, Pendekatan Normatif dan Deskriptif dalam Studi Islam (Telaah atas Karya Charles J. Adams) Melalui <http: / cfis.uii, ac.id/indeks. php (7 / 01/ 2010)

${ }^{24}$ Muhammad Latif Fauzi, Pendekatan Normatif dan Deskriptif dalam Studi Islam (Telaah atas Karya Charles J. Adams) Melalui <http: / cfis.uii, ac.id/indeks. php (7 / 01/ 2010)

25Jamali Sahrodi, Metodologi Studi Islam; Menelusuri Jejak Historis Kajian Islam Ala Sarjana Orientalsi, (Bandung: Pustaka Setia, 2008), Cet.I, h. 60

26Muhammad Latif Fauzi, Pendekatan Normatif dan Deskriptif dalam Studi Islam (Telaah atas 
Karya Charles J. Adams) Melalui <http: / cfis.uii, ac.id/indeks. php (7 / 01/ 2010)

27(Musim) haji adalah beberapa bulan yang dimaklumi, barangsiapa yang menetapkan niatnya dalam bulan itu akan mengerjakan haji, Maka tidak boleh rafats, berbuat fasik dan berbantah-bantahan di dalam masa mengerjakan haji. dan apa yang kamu kerjakan berupa kebaikan, niscaya Allah mengetahuinya. Berbekallah, dan Sesungguhnya sebaik-baik bekal adalah takwa ,dan bertakwalah kepada-Ku Hai orang-orang yang berakal.

${ }^{28}$ Ambillah zakat dari sebagian harta mereka, dengan zakat itu kamu membersihkandan mensucikan mereka dan mendoalah untuk mereka. Sesungguhnya doa kamu itu (menjadi) ketenteraman jiwa bagi mereka. dan Allah Maha mendengar lagi Maha Mengetahui. 